\title{
Chitinophaga ginsengisegetis sp. nov. and Chitinophaga ginsengisoli sp. nov., isolated from soil of a ginseng field in South Korea
}

\author{
Hyung-Gwan Lee, ${ }^{1}$ Dong-Shan An, ${ }^{1}$ Wan-Taek Im, ${ }^{1}$ Qing-Mei Liu, ${ }^{1}$ \\ Ju-Ryun $\mathrm{Na}^{2}{ }^{2}$ Dong Ha Cho, ${ }^{3}$ Cheng Wu Jin, ${ }^{3}$ Sung-Taik Lee ${ }^{1}$ \\ and Deok-Chun Yang ${ }^{2}$

\begin{abstract}
${ }^{1}$ Department of Biological Sciences, Korea Advanced Institute of Science and Technology, 373-1, Guseong-dong, Yuseong-gu, Daejeon 305-701, Republic of Korea Kyung Hee University, Seocheon, Kihung Yongin, Kyunggi 449-701, Republic of Korea

${ }^{3}$ Kangwon National University, School of Bioscience and Biotechnology, Chunchon 200-701, Republic of Korea
\end{abstract} \\ ${ }^{2}$ Department of Oriental Medicinal Material and Processing, College of Life Science,
}

Correspondence

Deok-Chun Yang

dcyang@khu.ac.kr

Sung-Taik Lee

e_stlee@kaist.ac.kr
The genus Chitinophaga was originally described by Sangkhobol \& Skerman (1981) to include strains of filamentous, chitinolytic, gliding bacteria which transform into spherical bodies on ageing. Recently, Kämpfer et al. (2006) proposed Chitinophaga skermanii sp. nov. and reclassified [Flexibacter] filiformis, [Flexibacter] sancti, [Cytophaga] arvensicola and [Flexibacter] japonensis as members of the genus Chitinophaga. At the time of writing, the genus Chitinophaga contains six species with validly published names; Chitinophaga pinensis (the type species), Chitinophaga filiformis, Chitinophaga sancti, Chitinophaga

The GenBank/EMBL/DDBJ accession numbers for the 16S rRNA gene sequences of strains Gsoil $040^{\top}$ and Gsoil $052^{\top}$ are AB264798 and $A B 245374$, respectively. arvensicola, Chitinophaga japonensis and Chitinophaga skermanii.

In this paper, a polyphasic taxonomic approach was used to characterize novel bacterial strains that were isolated from the soil of a ginseng field in South Korea. Two strains, Gsoil $040^{\mathrm{T}}$ and Gsoil $052^{\mathrm{T}}$, were found to represent two novel species of the genus Chitinophaga.

Strains Gsoil $040^{\mathrm{T}}$ and Gsoil $052^{\mathrm{T}}$ were originally isolated from the soil of a ginseng field from Pocheon province, South Korea. This soil sample was thoroughly suspended with $50 \mathrm{mM}$ phosphate buffer ( $\mathrm{pH}$ 7.0) and the suspension was spread on one-fifth-strength modified R2A agar [containing $\left(\mathrm{l}^{-1}\right) 0.25 \mathrm{~g}$ tryptone, $0.25 \mathrm{~g}$ peptone, $0.25 \mathrm{~g}$ yeast extract, $0.125 \mathrm{~g}$ malt extract, $0.125 \mathrm{~g}$ beef extract, 
0.25 g Casamino acids, 0.25 g Soytone, $0.5 \mathrm{~g}$ glucose, $0.3 \mathrm{~g}$ soluble starch, $0.2 \mathrm{~g}$ xylan, $0.3 \mathrm{~g}$ sodium pyruvate, $0.3 \mathrm{~g}$ $\mathrm{K}_{2} \mathrm{HPO}_{4}, 0.05 \mathrm{~g} \mathrm{MgSO}_{4}, 0.05 \mathrm{~g} \mathrm{CaCl}_{2}$ and $15 \mathrm{~g}$ agar] plates after serial dilution with $50 \mathrm{mM}$ phosphate buffer ( $\mathrm{pH}$ 7.0). The plates were incubated at $30^{\circ} \mathrm{C}$ for one month. Single colonies on the plates were purified by transferring them onto new plates and were then incubated again on fullstrength modified R2A or half-strength modified R2A. The purified colonies were tentatively identified by partial sequences of the 16S rRNA gene (Im et al., 2005). They were routinely cultured on R2A agar at $30^{\circ} \mathrm{C}$ and maintained as a glycerol suspension $\left(20 \%\right.$, w/v) at $-70{ }^{\circ} \mathrm{C}$.

The Gram reaction was performed by the non-staining method as described by Buck (1982). Cell morphology was observed under a light microscope (Nikon) at $\times 1000$, with cells grown for 3 days at $30^{\circ} \mathrm{C}$ on R2A agar. Catalase activity was determined by assessing bubble production in $3 \%(\mathrm{v} / \mathrm{v})$ $\mathrm{H}_{2} \mathrm{O}_{2}$ and oxidase activity was determined using $1 \%(\mathrm{w} / \mathrm{v})$ tetramethyl-p-phenylenediamine. Carbon source utilization and enzyme activities were tested by using the API $20 \mathrm{NE}$, API ID 32 GN and API ZYM test kits (bioMérieux). The ability to grow under anaerobic conditions was tested in serum bottles by adding sodium thioglycolate $\left(1 \mathrm{~g} \mathrm{l}^{-1}\right)$ to R2A broth and substituting the upper air layer with nitrogen gas. Tests for the degradation of DNA, in which DNase agar (Scharlau) plates were flooded with $1 \mathrm{M} \mathrm{HCl}$, casein, chitin, starch (Atlas 1993), lipid (Kouker \& Jaeger, 1987), xylan and cellulose (Ten et al., 2004), were performed and then evaluated after 10 days. Growth at different temperatures $(4,15$, $20,25,30,37$ and $42^{\circ} \mathrm{C}$ ) and various $\mathrm{pH}$ values ( $\mathrm{pH} 5.0$ 10.0 at intervals of $0.5 \mathrm{pH}$ units) was assessed after 10 days incubation. Salt tolerance was tested on R2A agar supplemented with $1-10 \%(\mathrm{w} / \mathrm{v}) \mathrm{NaCl}$ after 5 days incubation. Growth on nutrient agar and trypticase soy agar (TSA) was also evaluated at $30^{\circ} \mathrm{C}$. Flexirubin-like pigments were observed by flooding the plates with $20 \%(\mathrm{w} / \mathrm{v})$ potassium hydroxide (Fautz \& Reichenbach, 1980).

Extraction of genomic DNA was performed with a commercial genomic DNA extraction kit (Solgent) and PCR-mediated amplification of the $16 \mathrm{~S}$ rRNA gene and sequencing of the purified PCR product were carried out according to Kim et al. (2005). Full sequences of the 16S rRNA gene were compiled using SeqMan software (DNASTAR). The $16 \mathrm{~S}$ rRNA gene sequences of related taxa were obtained from GenBank. Multiple alignments were performed with CLUSTAL_X (Thompson et al., 1997). Gaps were edited with BioEdit (Hall, 1999). Evolutionary distances were calculated using the Kimura two-parameter model (Kimura, 1983). Phylogenetic trees were constructed by using a neighbour-joining method (Saitou \& Nei, 1987) and maximum-parsimony (Fitch, 1971) using the MEGA3 software package (Kumar et al., 2004) with bootstrap values based on 1000 replications (Felsenstein, 1985).

For the measurement of $\mathrm{G}+\mathrm{C}$ content of the chromosomal DNA, genomic DNA of the novel strains was extracted and purified as described by Moore \& Dowhan (1995) and was then enzymically degraded into nucleosides. DNA G $+\mathrm{C}$ content was determined as described by Mesbah et al. (1989) using a reversed-phase HPLC. Isoprenoid quinones were extracted with chloroform/methanol $(2: 1, \mathrm{v} / \mathrm{v})$, evaporated under vacuum conditions, and reextracted in n-hexane/ water $(1: 1, \mathrm{v} / \mathrm{v})$. The crude $\mathrm{n}$-hexane-quinone solution was purified using silica Sep-Pak Vac cartridges (Waters) and subsequently analysed by HPLC as described previously (Hiraishi et al., 1996). Cellular fatty acid profiles were determined for strains grown on TSA (Difco) for 2 days. The cellular fatty acids were saponified, methylated and extracted according to the protocol of the Sherlock Microbial Identification System (MIDI). The fatty acids were analysed using a gas chromatograph (6890; Hewlett Packard) and identified by the Microbial Identification software package (Sasser, 1990). Polyamines were extracted and analysed according to Busse \& Auling (1988) and Schenkel et al. (1995), respectively.

Cells of strains Gsoil $040^{\mathrm{T}}$ and Gsoil $052^{\mathrm{T}}$ were aerobic, Gram-negative, non-motile and non-spore-forming rods. When grown on R2A agar plates for three days, colonies of both strains were smooth, circular, yellowish and 1.5$4.0 \mathrm{~mm}$ in diameter. Both isolates grew well on nutrient agar and TSA. Tests for flexirubin pigmentation were positive for both strains. The presence of flexirubin pigments was demonstrated by a fast shift of colony colour from yellow to reddish brown after the addition of $20 \% \mathrm{KOH}$ and the retention of the original colour upon the addition of $\mathrm{HCl}$. Other physiological characteristics of strains Gsoil $040^{\mathrm{T}}$ and Gsoil $052^{\mathrm{T}}$ are summarized in the species descriptions and comparisons of selective characteristics with closely related type strains are shown in Table 1.

Almost complete 16S rRNA gene sequences (1521 and $1525 \mathrm{bp}$, respectively) for strains Gsoil $040^{\mathrm{T}}$ and Gsoil $052^{\mathrm{T}}$ were determined and were subjected to comparative analysis. Phylogenetic analysis based on 16S rRNA gene sequences indicated that both novel strains belong to the genus Chitinophaga (Fig. 1). However, the 16S rRNA gene sequence similarity between strains Gsoil $040^{\mathrm{T}}$ and Gsoil $052^{\mathrm{T}}$ was $93.3 \%$, suggesting that they represent separate species (Stackebrandt \& Goebel, 1994). Strain Gsoil $040^{\mathrm{T}}$ showed highest $16 \mathrm{~S}$ rRNA gene sequence similarity to $C$. arvensicola IAM $12650^{\mathrm{T}}(96.5 \%)$, followed by C. japonensis IFO $16041^{\mathrm{T}}(94.5 \%)$, C. sancti IFO $15057^{\mathrm{T}}(93.4 \%)$, C. filiformis IFO $15056^{\mathrm{T}}(93.4 \%)$, C. skermanii CC-SG1B ${ }^{\mathrm{T}}$ $(92.0 \%)$ and C. pinensis UQM $2034^{\mathrm{T}}(91.9 \%)$. These values $(<97 \%)$ were low enough, according to Stackebrandt \& Goebel (1994), to place strain Gsoil $040^{\mathrm{T}}$ as a novel species in the genus Chitinophaga. Strain Gsoil $052^{\mathrm{T}}$ showed highest $16 \mathrm{~S}$ rRNA gene sequence similarity with $C$. filiformis IFO $15056^{\mathrm{T}}(99.6 \%)$, followed by C. pinensis UQM $2034^{\mathrm{T}}$ $(95.9 \%)$, C. sancti IFO $15057^{\mathrm{T}}(94.8 \%)$, C. japonensis IFO $16041^{\mathrm{T}}(94.2 \%)$, C. skermanii CC-SG1B ${ }^{\mathrm{T}}(94.1 \%)$ and C. arvensicola IAM $12650^{\mathrm{T}}(91.2 \%)$. Strain Gsoil $052^{\mathrm{T}}$ and $C$. filiformis shared a low DNA-DNA relatedness value of $38 \%$, which is well below the threshold (70\%) recommended for 
Table 1. Phenotypic characteristics of strains Gsoil $040^{\top}$, Gsoil $052^{\top}$ and related type strains

Strains: 1, C. ginsengisegetis sp. nov. Gsoil $040^{\mathrm{T}}$; 2, C. ginsengisoli sp. nov. Gsoil $052^{\mathrm{T}}$; 3, C. arvensicola DSM 3695 ${ }^{\mathrm{T}}$; 4, C. japonensis DSM $13484^{\mathrm{T}}$; 5, C. sancti DSM $784^{\mathrm{T}}$; 6, C. filiformis CCUG $12809^{\mathrm{T}}$; 7, C. skermanii CC-SG1B ${ }^{\mathrm{T}}$; 8 , C. pinensis DSM $2588^{\mathrm{T}}$. All the strains were isolated from soil. None of the strains showed acid production from glucose or $\mathrm{H}_{2} \mathrm{~S}$ production. All strains gave positive results for the assimilation of D-mannose and D-maltose. Data for taxa 3-8 are taken from Kämpfer et al. (2006). The carbon assimilation tests were read after $48 \mathrm{~h}$ incubation. +, Positive; -, negative; ND, not determined.

\begin{tabular}{|c|c|c|c|c|c|c|c|c|}
\hline Characteristic & 1 & 2 & 3 & 4 & 5 & 6 & 7 & 8 \\
\hline Pigment & Yellow & Yellow & Yellow-orange & Yellow-orange & Golden yellow & Golden yellow & Yellow & Yellow \\
\hline Cell length $(\mu \mathrm{m})$ & $1.1-1.3$ & $1.2-1.6$ & $0.6-4$ & $2-18$ & $2-15$ & $30-80$ & $1-2$ & $<40$ \\
\hline Gliding movement & - & - & - & + & + & + & - & + \\
\hline Oxidase & - & + & + & + & ND & + & + & + \\
\hline Catalase & - & + & + & + & - & - & + & + \\
\hline Growth at $37^{\circ} \mathrm{C}$ & + & + & - & + & - & + & + & + \\
\hline Highest $\mathrm{NaCl}$ tolerance $(\%, \mathrm{w} / \mathrm{v})$ & 2.0 & $<1.0$ & 2.0 & 2.0 & 1.0 & 0.3 & ND & ND \\
\hline Urease & + & + & - & ND & ND & ND & - & + \\
\hline Gelatin liquefaction & + & + & - & + & + & + & + & + \\
\hline Chitin degradation & - & + & - & - & - & + & $\mathrm{ND}$ & + \\
\hline \multicolumn{9}{|l|}{ Assimilation of: } \\
\hline$N$-Acetyl-D-glucosamine & + & + & + & + & - & - & + & + \\
\hline L-Arabinose & + & + & $+^{*}$ & + & $+^{*}$ & - & - & + \\
\hline Gluconate & $+^{*}$ & $+^{*}$ & - & - & $+^{*}$ & - & - & - \\
\hline$\alpha$-D-Melibiose & + & + & + & + & $+\dagger$ & $+^{*}$ & $+^{*}$ & - \\
\hline L-Rhamnose & + & $+^{*}$ & + & + & - & - & - & $+^{*}$ \\
\hline D-Ribose & - & - & + & - & - & - & - & - \\
\hline Sucrose & + & + & $+^{*}$ & + & - & + & - & $+^{*}$ \\
\hline Salicin & + & + & + & + & - & + & + & $+^{*}$ \\
\hline Inositol & $+^{*}$ & $+^{*}$ & - & - & - & - & - & - \\
\hline DNA G $+C$ content $(\mathrm{mol} \%)$ & 47.1 & 48.4 & 46.0 & 49.8 & 43.3 & 45.0 & 40.7 & 45.2 \\
\hline
\end{tabular}

${ }^{\star}$ Positive after 7 days incubation.

$\dagger$ Positive after 2 weeks incubation.

the delineation of bacterial species (Wayne et al., 1987). It is clear from DNA-DNA hybridization experiments that strain Gsoil $052^{\mathrm{T}}$ belongs to a separate genomic species in the genus Chitinophaga.

The DNA G $+\mathrm{C}$ contents of strains Gsoil $040^{\mathrm{T}}$ and Gsoil $052^{\mathrm{T}}$ were 47.1 and $48.4 \mathrm{~mol} \%$, respectively. The major respiratory quinone was MK-7. The major polyamine of both strains was homospermidine, as is the case for the other recognized species of the genus Chitinophaga (Kämpfer et al., 2006). As shown in Table 2, the major fatty acids of both strains were iso- $\mathrm{C}_{15: 0,}, \mathrm{C}_{16: 1} \omega 5 c$ and the hydroxy fatty acids were iso- $\mathrm{C}_{17: 0} 3-\mathrm{OH}$ and iso- $\mathrm{C}_{15: 0} 3-\mathrm{OH}$, which are consistent with those found in other species of the genus Chitinophaga (Kämpfer et al., 2006). However, qualitative and quantitative differences in the fatty acid contents could be used to distinguish strains Gsoil $040^{\mathrm{T}}$ and Gsoil $052^{\mathrm{T}}$ from the other species in the genus Chitinophaga (Table 2).

On the basis of these data and the observations described above, both strains Gsoil $040^{\mathrm{T}}$ and Gsoil $052^{\mathrm{T}}$ should be assigned to the genus Chitinophaga as representing two novel species, for which the names Chitinophaga ginsengisegetis sp. nov. and Chitinophaga ginsengisoli sp. nov. are proposed.

\section{Description of Chitinophaga ginsengisegetis sp. nov.}

Chitinophaga ginsengisegetis (gin.seng.i.se.ge.ti's. N.L. n. ginsengum ginseng; L. n. seges segetis a field; N.L. gen. n. ginsengisegetis of a ginseng field, the source of the organism).

Cells are Gram-negative, aerobic, non-motile and rodshaped. Cells are $0.4-0.6 \mu \mathrm{m}$ in width and $1.1-1.3 \mu \mathrm{m}$ in length after 3 days culture on R2A agar. Colonies grown on R2A agar for 3 days are smooth, circular, convex, transparent and yellowish. Grows well at temperatures of 15$42{ }^{\circ} \mathrm{C}$ and at pH $5.5-8.5$, but grows slowly at $4{ }^{\circ} \mathrm{C}$. Growth occurs in the absence of $\mathrm{NaCl}$ and in the presence of $2.0 \%$ $(\mathrm{w} / \mathrm{v}) \mathrm{NaCl}$, but growth does not occur at $3 \%(\mathrm{w} / \mathrm{v}) \mathrm{NaCl}$. Does not reduce nitrate. Anaerobic growth does not occur. Does not degrade DNA, chitin or xylan. Substrate utilization, enzyme production and other physiological characteristics are shown in Table 1 . In addition to the data in Table 1, also able to utilize $N$-acetyl-D-glucosamine, 


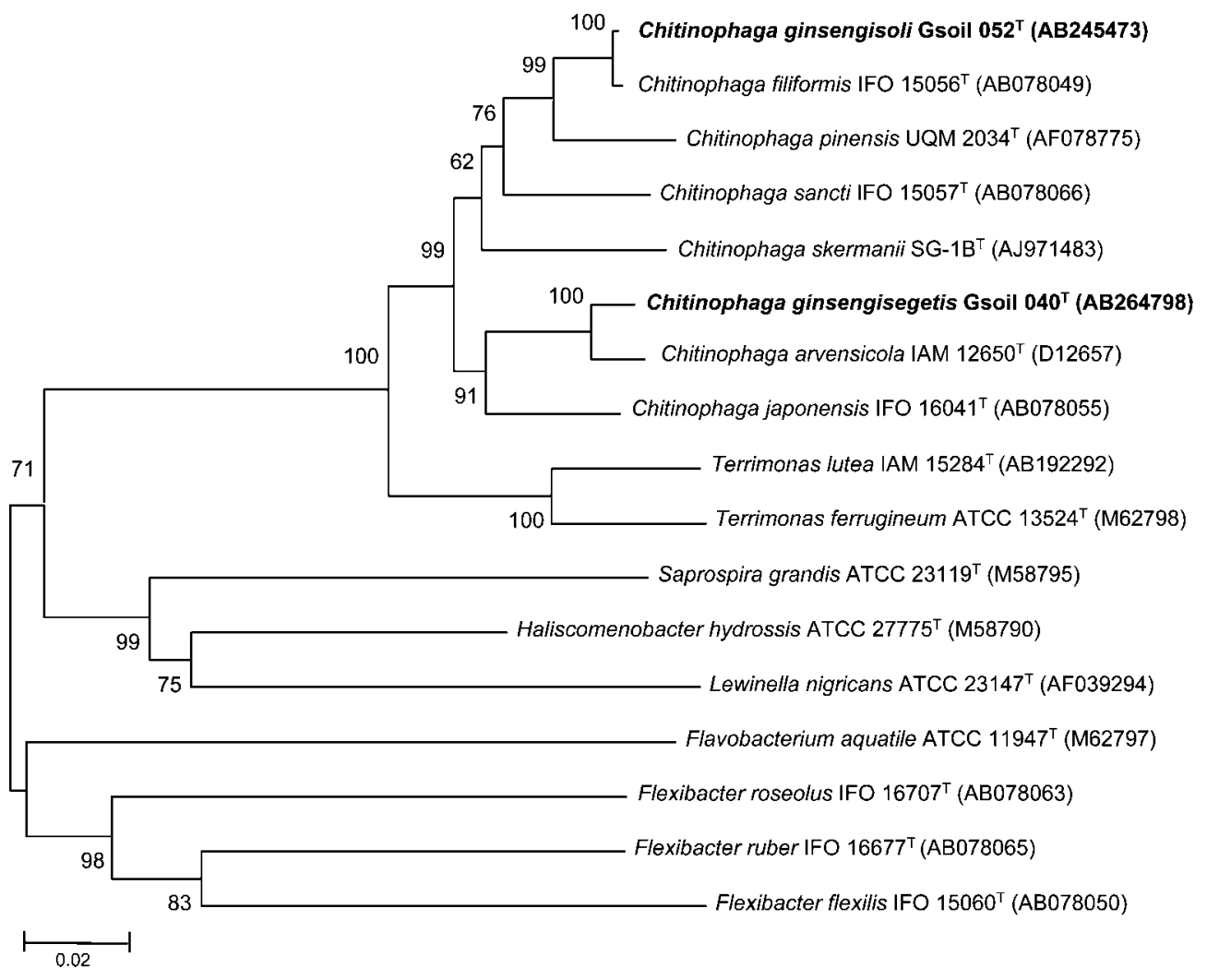

Fig. 1. Phylogenetic tree constructed from a comparative analysis of $16 \mathrm{~S}$ rRNA gene sequences showing the relationships of Chitinophaga ginsengisegetis sp. nov. Gsoil $040^{\top}$ and Chitinophaga ginsengisoli sp. nov. Gsoil $052^{\top}$ with other related species. This tree was constructed using the neighbour-joining method (Saitou \& Nei, 1987) with a Kimura (1983) twoparameter distance matrix and pairwise deletion. Bootstrap values (expressed as percentages of 1000 replications) greater than $60 \%$ are shown at the branch points. Bar, 0.02 substitutions per 1 nucleotide position.

arabinose, L-fucose, glucose, maltose, mannose, D-melibiose, L-proline, rhamnose, salicin, D-sorbitol and sucrose as sole carbon sources. Positive results for the utilization of L-alanine, gluconate, histidine, inositol and L-serine are found after 7 days of incubation. Utilization of 5-ketogluconate and malate is positive after 14 days of incubation. Does not utilize acetate, adipate, caprate, citrate, glycogen, 3-hydroxybenzoate, 4-hydroxybenzoate, 3-hydroxybutyrate, 2-ketogluconate, itaconate, L-lactate, malonate, mannitol, phenylacetate, propionate, D-ribose, D-sorbitol, suberate or valerate. According to the API ZYM gallery, produces $N$-acetyl- $\beta$-glucosaminidase, acid phosphatase, alkaline phosphatase, cystine arylamidase, esterase (C4), $\alpha$ fucosidase, $\alpha$-galactosidase, $\alpha$-glucosidase, leucine arylamidase, trypsin and valine arylamidase, but not chymotrypsin, esterase lipase (C8), $\beta$-galactosidase, $\beta$-glucosidase, $\beta$-glucuronidase, lipase (C14), $\alpha$-mannosidase or naphthol-ASBI-phosphohydrolase. According to the API 20 NE gallery, gives positive results for arginine dihydrolase, $\beta$-galactosidase and urease and is weakly positive for glucose fermentation and gelatin hydrolysis. Negative results for nitrate reduction and tryptophan degradation. Flexirubin pigmentation is positive. $\mathrm{MK}-7$ is the predominant menaquinone and iso- $\mathrm{C}_{15: 0}$ and $\mathrm{C}_{16: 1} \omega 5 \mathrm{c}$ are the predominant cellular fatty acids. The $\mathrm{G}+\mathrm{C}$ content of the genomic DNA is $47.1 \mathrm{~mol} \%$.

The type strain, Gsoil $040^{\mathrm{T}}$ (= KCTC $12654^{\mathrm{T}}=\mathrm{DSM}$ $18108^{\mathrm{T}}$ ) was isolated from the soil of a ginseng field in Pocheon province, South Korea.

\section{Description of Chitinophaga ginsengisoli sp. nov.}

Chitinophaga ginsengisoli (gin.sen.gi.so'li. N.L. n. ginsengum ginseng; L. n. solum soil; N.L. gen. n. ginsengisoli of soil of a ginseng field, the source of the organism).

Cells are Gram-negative, aerobic, non-motile and rodshaped. Cells are $0.6-0.8 \mu \mathrm{m}$ in diameter and $1.2-1.6 \mu \mathrm{m}$ in length after 3 days culture on R2A agar. Colonies grown on R2A agar for 3 days are smooth, circular, convex, transparent and yellowish. Grows well at temperatures of 15$42{ }^{\circ} \mathrm{C}$ and at $\mathrm{pH}$ 5.5-8.5. Growth occurs in the absence of $\mathrm{NaCl}$ and in the presence of $<1.0 \%$ (w/v) $\mathrm{NaCl}$. Does not reduce nitrate. Anaerobic growth does not occur. Able to degrade chitin, but not DNA or xylan. Substrate utilization, 
Table 2. Cellular fatty acid profiles of strains Gsoil $040^{\top}$, Gsoil $052^{\top}$ and related type strains of species of the genus Chitinophaga

Strains: 1, C. ginsengisegetis sp. nov. Gsoil $040^{\mathrm{T}} ; 2$, C. ginsengisoli sp. nov. Gsoil $052^{\mathrm{T}} ; 3$, C. arvensicola DSM $3695^{\mathrm{T}}$; 4, C. japonensis DSM $13484^{\mathrm{T}}$; 5, C. sancti DSM $784^{\mathrm{T}} ; 6$, C. filiformis CCUG $12809^{\mathrm{T}} ; 7$, C. skermanii CC-SG1B ${ }^{\mathrm{T}}$; 8, C. pinensis DSM $2588^{\mathrm{T}}$. Data for taxa 3-8 are from Kämpfer et al. (2006). Summed feature 2 comprises any combination of $\mathrm{C}_{12: 0}$ aldehyde, $\mathrm{C}_{14: 0}$ 3-OH and/or iso- $\mathrm{C}_{16: 1}$. Summed feature 3 comprises any combination of iso- $\mathrm{C}_{15: 0} 2-\mathrm{OH}$ and/or $\mathrm{C}_{16: 1} \omega 7 c$. Summed feature 4 comprises any combination of iso- $\mathrm{C}_{17: 1} \mathrm{I}$ and/or anteiso- $\mathrm{C}_{17: 1} \mathrm{~B}$. Values in bold type denote the major cellular fatty acids.

\begin{tabular}{|c|c|c|c|c|c|c|c|c|}
\hline & 1 & 2 & 3 & 4 & 5 & 6 & 7 & 8 \\
\hline Unknown 13.565 & & 2.1 & 3.6 & 3.1 & 3.2 & 2.5 & 4.4 & 2.6 \\
\hline $\mathrm{C}_{14: 0}$ & 2.1 & 0.7 & 1.4 & 0.5 & 0.7 & 0.9 & 1.8 & 0.7 \\
\hline $\mathrm{C}_{15: 0} 2-\mathrm{OH}$ & & & 0.3 & & & & & \\
\hline iso- $\mathrm{C}_{15: 0} 3-\mathrm{OH}$ & 3.7 & 2.8 & 3.0 & 2.4 & 3.4 & 3.3 & 2.6 & 3.1 \\
\hline iso- $\mathrm{C}_{15: 0}$ & 42.5 & 38.1 & 35.3 & 40.0 & 44.0 & 37.3 & 47.3 & 30.4 \\
\hline anteiso- $\mathrm{C}_{15: 0}$ & 0.7 & 0.7 & 0.6 & 0.5 & & & & \\
\hline Unknown 11.543 & & & 0.5 & & & & 0.8 & \\
\hline $\mathrm{C}_{15: 0}$ & & & 0.4 & & & & 0.4 & 0.4 \\
\hline Unknown 14.959 & & & 0.3 & & & & 0.4 & 0.3 \\
\hline Summed feature 2 & & 0.6 & 0.4 & 0.5 & & & 0.4 & \\
\hline iso- $\mathrm{C}_{17: 1} \omega 9 c$ & & & 0.3 & & 1.1 & & & \\
\hline Summed feature 3 & 3.1 & 6.9 & 3.7 & 3.3 & 16.0 & 11.2 & 3.5 & 7.7 \\
\hline Summed feature 4 & & & & 1.3 & 0.8 & & 0.4 & \\
\hline $\mathrm{C}_{16: 0} 10$ methyl & & & 0.4 & 0.9 & & & & \\
\hline $\mathrm{C}_{16: 1} \omega 11 c$ & & & 0.5 & 1.0 & 0.9 & & 0.4 & 1.9 \\
\hline $\mathrm{C}_{16: 1} \omega 5 c$ & 29.4 & 29.0 & 33.6 & 22.2 & 13.5 & 25.5 & 24.4 & 33.2 \\
\hline $\mathrm{C}_{16: 0} 2-\mathrm{OH}$ & & & & 3.0 & 0.7 & 1.1 & & 0.7 \\
\hline $\mathrm{C}_{16: 0}$ & 5.6 & 4.8 & 5.1 & 3.0 & 4.2 & 4.3 & 3.5 & 4.2 \\
\hline iso- $\mathrm{C}_{16: 0}$ & & & 0.3 & & & & & \\
\hline iso- $\mathrm{C}_{16: 0} 3-\mathrm{OH}$ & & & 0.5 & 0.4 & & & 0.4 & 0.4 \\
\hline $\mathrm{C}_{16: 0} 3-\mathrm{OH}$ & 2.1 & 1.5 & 1.7 & 0.8 & 0.5 & 1.2 & 1.6 & 1.2 \\
\hline anteiso- $\mathrm{C}_{17: 0}$ & & 0.4 & & 0.4 & & & & \\
\hline $\mathrm{C}_{17: 0} 2-\mathrm{OH}$ & & & 0.4 & 0.4 & & & & \\
\hline iso- $\mathrm{C}_{17: 0}$ & & 0.7 & 0.4 & 1.8 & 0.6 & & 0.6 & 0.4 \\
\hline Unknown 16.582 & 0.3 & 0.4 & 0.8 & 1.1 & 1.3 & 0.9 & 0.7 & 1.1 \\
\hline iso- $\mathrm{C}_{17: 0} 3-\mathrm{OH}$ & 8.5 & 11.3 & 5.9 & 13.0 & 9.1 & 11.8 & 5.0 & 11.5 \\
\hline $\mathrm{C}_{18: 0}$ & 1.2 & & & & & & & \\
\hline $\mathrm{C}_{18: 3} \omega 6 c$ & 0.9 & & & & & & & \\
\hline
\end{tabular}

enzyme production and other physiological characteristics are indicated in Table 1. In addition to the data in Table 1, can also utilize $\mathrm{N}$-acetyl-D-glucosamine, arabinose, glucose, maltose, mannose, D-melibiose, L-proline, salicin, Dsorbitol and sucrose as sole carbon sources. Positive results are also found for gluconate, inositol and rhamnose after 7 days incubation. After 14 days incubation, gives a positive result for L-fucose and 5-ketogluconate. Does not utilize acetate, adipate, L-alanine, caprate, citrate, glycogen, histidine, 3-hydroxybenzoate, 4-hydroxybenzoate, 3-hydroxybutyrate, itaconate, 2-ketogluconate, L-lactate, malate, malonate, mannitol, phenylacetate, propionate, D-ribose, L-serine, D-sorbitol, suberate or valerate. According to the API ZYM gallery, gives positive results for $N$-acetyl- $\beta$ glucosaminidase, acid phosphatase, alkaline phosphatase, cystine arylamidase, esterase (C4), esterase lipase (C8), $\alpha$-fucosidase, $\alpha$-galactosidase, $\beta$-galactosidase, $\alpha$-glucosidase, leucine arylamidase, trypsin and valine arylamidase and is weakly positive for chymotrypsin and $\beta$-glucosidase. Negative for $\beta$-glucuronidase, lipase (C14), naphthol-ASBI-phosphohydrolase and $\alpha$-mannosidase. According to the API 20NE gallery, gives positive results for arginine dihydrolase, $\beta$-galactosidase, gelatin hydrolysis, glucose fermentation and urease, but is negative for nitrate reduction and tryptophan degradation. Flexirubin pigmentation is positive. MK-7 is the predominant menaquinone and iso- $\mathrm{C}_{15: 0}$ and $\mathrm{C}_{16: 1} \omega 5 c$ are the predominant cellular fatty acids. The $\mathrm{G}+\mathrm{C}$ content of the genomic DNA is $48.4 \mathrm{~mol} \%$.

The type strain, Gsoil $052^{\mathrm{T}}\left(=\mathrm{KCTC} 12592^{\mathrm{T}}=\mathrm{DSM}\right.$ $18017^{\mathrm{T}}$ ) was isolated from the soil of a ginseng field in Pocheon province, South Korea. 


\section{Acknowledgements}

This work was supported by a grant from the Plant Diversity Research Center of the 21st Century Frontier Research Program (code \# PF06222-00) funded by Ministry of Science and Technology of the Korean government.

\section{References}

Atlas, R. M. (1993). Handbook of Microbiological Media. Edited by L. C. Parks. Boca Raton, FL: CRC Press.

Buck, J. D. (1982). Nonstaining (KOH) method for determination of Gram reactions of marine bacteria. Appl Environ Microbiol 44, 992-993.

Busse, J. \& Auling, G. (1988). Polyamine pattern as a chemotaxonomic marker within the Proteobacteria. Syst Appl Microbiol 11, 1-8.

Fautz, E. \& Reichenbach, H. (1980). A simple test for flexirubin-type pigments. FEMS Microbiol Lett 8, 87-91.

Felsenstein, J. (1985). Confidence limits on phylogenies: an approach using the bootstrap. Evolution 39, 783-791.

Fitch, W. M. (1971). Toward defining the course of evolution: minimum change for a specific tree topology. Syst Zool 20, 406-416.

Hall, T. A. (1999). BioEdit: a user-friendly biological sequence alignment editor and analysis program for Windows 95/98/NT. Nucleic Acids Symp Ser 41, 95-98.

Hiraishi, A., Ueda, Y., Ishihara, J. \& Mori, T. (1996). Comparative lipoquinone analysis of influent sewage and activated sludge by highperformance liquid chromatography and photodiode array detection. J Gen Appl Microbiol 42, 457-469.

Im, W.-T., Jung, H.-M., Cui, Y.-S., Liu, Q.-M., Zhang, S.-L. \& Lee, S.-T. (2005). Cultivation of the three hundreds of bacterial species from soil of a ginseng field and mining the novel lineage bacteria. In Proceedings of the International Meeting of the Federation of Korean Microbiological Societies, abstract A035, p. 169. Seoul: Federation of Korean Microbiological Societies.

Kämpfer, P., Young, C. C., Sridhar, K. R., Arun, A. B., Lai, W. A., Shen, F. T. \& Rekha, P. D. (2006). Transfer of [Flexibacter] sancti, [Flexibacter] filiformis, [Flexibacter] japonensis, and [Cytophaga] arvensicola to the genus Chitinophaga and description of Chitinophaga skermanii sp. nov. Int J Syst Evol Microbiol 56, 2223-2228.

Kim, M. K., Im, W.-T., Ohta, H., Lee, M. \& Lee, S.-T. (2005). Sphingopyxis granuli sp. nov., a $\beta$-glucosidase-producing bacterium in the family Sphingomonadaceae in $\alpha-4$ subclass of the Proteobacteria. J Microbiol 43, 152-157.
Kimura, M. (1983). The Neutral Theory of Molecular Evolution. Cambridge: Cambridge University Press.

Kouker, G. \& Jaeger, K.-E. (1987). Specific and sensitive plate assay for bacterial lipase. Appl Environ Microbiol 53, 211-213.

Kumar, S., Tamura, K. \& Nei, M. (2004). MEGA3: Integrated software for molecular evolutionary genetics analysis and sequence alignment. Brief Bioinform 5, 150-163.

Mesbah, M., Premachandran, U. \& Whitman, W. B. (1989). Precise measurement of the $\mathrm{G}+\mathrm{C}$ content of deoxyribonucleic acid by highperformance liquid chromatography. Int J Syst Bacteriol 39, 159-167.

Moore, D. D. \& Dowhan, D. (1995). Preparation and analysis of DNA. In Current Protocols in Molecular Biology, pp. 2-11. Edited by F. W. Ausubel, R. Brent, R. E. Kingston, D. D. Moore, J. G. Seidman, J. A. Smith \& K. Struhl. New York: Wiley.

Saitou, N. \& Nei, M. (1987). The neighbor-joining method: a new method for reconstructing phylogenetic trees. Mol Biol Evol 4, 406-425.

Sangkhobol, V. \& Skerman, V. B. D. (1981). Chitinophaga, a new genus of chitinolytic myxobacteria. Int J Syst Bacteriol 31, 285-293.

Sasser, M. (1990). Identification of Bacteria by Gas Chromatography of Cellular Fatty Acids. MIDI Technical Note 101. Newark, DE: MIDI Inc.

Schenkel, E., Berlaimont, V., Dubois, J., Helson-Cambier, M. \& Hanocq, M. (1995). Improved high-performance liquid chromatographic method for the determination of polyamines as their benzoylated derivatives: application to P388 cancer cells. J Chromatogr B Biomed Appl 668, 189-197.

Stackebrandt, E. \& Goebel, B. M. (1994). Taxonomic note: a place for DNA-DNA reassociation and 16S rRNA sequence analysis in the present species definition in bacteriology. Int $J$ Syst Bacteriol 44, 846-849.

Ten, L. N., Im, W.-T., Kim, M.-K., Kang, M.-S. \& Lee, S.-T. (2004). Development of a plate technique for screening of polysaccharidedegrading microorganisms by using a mixture of insoluble chromogenic substrates. J Microbiol Methods 56, 375-382.

Thompson, J. D., Gibson, T. J., Plewniak, F., Jeanmougin, F. \& Higgins, D. G. (1997). The CLUSTAL_X windows interface: flexible strategies for multiple sequence alignment aided by quality analysis tools. Nucleic Acids Res 25, 4876-4882.

Wayne, L. G., Brenner, D. J., Colwell, R. R., Grimont, P. A. D., Kandler, O., Krichevsky, M. I., Moore, L. H., Moore, W. E. C., Murray, R. G. E. \& other authors (1987). International Committee on Systematic Bacteriology. Report of the ad hoc committee on reconciliation of approaches to bacterial systematics. Int J Syst Bacteriol 37, 463-464. 